\title{
Protective Role of Lycopene Against Diethylnitrosamine Induced Experimental Hepatocarcinogenesis
}

\author{
Inas Z.A. Abdallah and Hala A.H. Khattab \\ Nutrition and Food Science Dept., Faculty of Home Economics, \\ Helwan University.
}

\begin{abstract}
Lycopene was considered as a major carotenoid in the human diet for only the last few centuries. Recently lycopene has been found to possess chemoprotective effect against gastrointestinal tract, urinary bladder, prostate and breast cancers. In the present study, the protective effect of lycopene, the natural extract from tomato pomace against diethylnitrosamine (DEN)-induced hepatocellular carcinoma (HCC) formation in rats was investigated. Four groups of male albino rats at the age of 6 weeks were studied: 1) control (C), 2) DEN, i.p. injected 5 times with doses of $200 \mathrm{mg} / \mathrm{kg} \mathrm{b.w.}$, one dose every two days. 3) Lycopene, orally given $0.12 \mathrm{mg} / \mathrm{rat} /$ day. 4) Lycopene + DEN, the treatment with lycopene started 7 days before DEN injection and continued till the end of the experimental period. Rats in group 2 and 4 were treated with Phenobarbital (PB) at a dose of $500 \mathrm{ppm}$ in the drinking water as a tumor promoter. PB treatment started with the first injection of DEN and continued till the end of the experimental period. The results indicated that DEN caused HCC nodules as evidenced by a remarkable significant increase in $\alpha$-L-fucosidase and metalloproteinases (MMPs) enzyme activity in both serum and cytosol. Increased activity of these enzymes is a marker for both preneoplastic and carcinoma lesions. Administration of lycopene prior to DEN injection protected rats from DEN-induced HCC as evidenced by a significant descent in $\alpha$-L-fucosidase and MMPs enzymes activity in both serum and cytosol. The histological investigation of liver tissue confirmed these results. DEN group showed proliferated hyperplastic and anaplastic hepatocellular nodules surrounded with thin layer of fibroblastic cells, desmoplasia and inflammatory cells infiltrations, focal hepatic haemorrhages and necrosis. Meanwhile, lycopene + DEN group showed no histopathological changes. These results indicate that lycopene effectively inhibits DEN-induced hepatocarcinogenesis in rats.
\end{abstract}

\section{Introduction:}

Diethylnitrosamine (DEN) belongs to the relatively small group of carcinogens that has been thoroughly investigated. It induced hepatocellular carcinomas, which is one of the most common endpoints in cancer tests (Finnberg et al., 1999). DEN is considered to be a genotoxic carcinogen (Lewis et al., 1997). Since it is positive in tests for genotoxicity and can induce many types of DNA damage and alterations that lead to mutations by alkylation and other mechanisms (Nakae et al., 1997). Phenobarbital (PB) is a non-genotoxic carcinogen and has often been used as a tumor promoter (Osanai et al., 1997).

The presence of nitrosamines in foods is considered a risk factor because of their implication in causing gastrointestinal cancers of the pharynx, oesophagus, stomach, liver, pancreas and colorectum (Chhabra et al., 1996, Jen and Yuan, 1994 and Magee, 1996). Since nitrosamines are suspected carcinogens in humans because the intestinal bacterial flora can transform nitrites and nitrates in the food into powerful carcinogenic nitrosamines (Ames and Gold, 1990), the mechanisms of their toxic action have been the focus of attention for several years (Lin and Ho, 1994 and Yang and Smith, 1996).

Hepatocellular carcinoma (HCC) is one of the major malignant tumors in humans and causes more than 250,000 deaths annually worldwide (Kuo et al., 1998). It is closely associated with hepatic 
fibrosis or cirrhosis. Fibrosis arises from overproduction of extracellular matrix as a result of activation of hepatic nonparenchymal cells including kupffer cells and stellate cells (Pinzani et al., 1998). Activation of hepatic stellate cells in the fibrotic liver causes morphological changes in myofibroblast like cells, which is accompanied by synthesis of large quantities of extracellular matrix (Freidman, 1993). Prognosis of cirrhosis is very poor because the diagnosis is generally late, when the disease is so advanced that any effective treatment is precluded. Therefore, early detection is important in the management of this type of cancer (Pateron et al., 1994 and Tangkijvanich et al., 1999).

Recently, serum activity of alpha-Lfucosidase enzyme has been used as a marker for early detection of HCC in cirrhotics (Giardina et al., 1998). Alpha-Lfucosidase enzyme (Ec 3.2.1.51) is a lysosomal enzyme present in all mammalian cells. Deugnier (1984) showed that serum alpha-L-fucosidase activity was significantly increased in patients suffering from HCC when compared to healthy subjects.

Matrix metalloproteinases (MMPs) are a family of enzymes classified as zinc-dependent proteinases that collectively can degrade the various structural components of the extracellular matrix, their specific proteolytic targets have since expanded to many other extracellular proteins. These enzymes are involved in processes such as wound healing and also in tumor invasion and metastasis (Coussens and Werb, 1996 and Wood and Archer, 2001).

Lycopene has been a major carotenoid in the human diet for only the last few centuries. Tomatoes and tomato products account for the majority of lycopene ingestion (Clinton, 1998). Lycopene is a carotenoid present in human blood and tissues (Stahl and Sies., 1996). Rather high levels of lycopene was found in liver, adrenals, and tests, whereas other tissues such as lung and kidney contained less (Stahl et al., 1992 and Tanumihardjo et al., 1990). Absorption and distribution of lycopene into different tissues of rats was studied after application of radioactively labeled lycopene (Mathews -Roth et al., 1990). Liver was the major organ for lycopene accumulation. Recent interest in lycopene is due to the findings of an inverse association between dietary lycopene and risk for some types of cancer including those of oral cavity, pharynx, esophagus, stomach, rectum (Franceschi et al., 1994), liver (Matushima-Nishiwaki et al., 1995), colon (Franceschi et al., 1994 and Narisawa et al., 1998), urinary bladder (Helzlsouer et al., 1989 and Okajima et al., 1998), prostate (Giovannucci et al., 1995) and breast (Zhang et al., 1997).

The biological activities of lycopene include antioxidant activity, singlet oxygen quenching and peroxyl radical scavenging (Stahl and Sies, 1996). Although lycopene has no provitamin A activity, it exhibits other biological properties such as suppression of cell proliferation of human cancer cells (Levy et al., 1995) and induction of gap Junction communication (Zhang et al., 1991).

The objective of this study was to evaluate the protective effect of lycopene, the natural extract from tomato pomace against hepatocellular carcinoma induced by DEN, a potent hepatocarcinogen.

\section{Material and Methods:}

\section{Experimental animals:}

Male Sprague Dawley rats, 5 weeks of age were obtained from the animal house of the National Research Centre, Dokki, Egypt. They were kept for 12 weeks under good ventilation and illumination conditions and allowed standard casein diet and water ad libitum. Rats were acclimatized for one week before experimental use.

\section{Treatment: DEN}

DEN (C4 H10 NO2) was purchased from Sigma Chemical Co. (St Louis, MO. USA). It was in the form of solution packaged in a $100 \mathrm{ml}$ serum bottle with butyl rubber stopper and aluminum tear steal. The bottle content was dissolved in $100 \mathrm{ml}$ saline to make a $1 \%$ solution. Tumor initiation was achieved by 5 times injection with DEN at a dose of $200 \mathrm{mg} / \mathrm{kg}$ b.w., one dose every two days according to Ito et al. (1998). 
PB:

PB was purchased from Pfizer Pharm. Ind. Co., Cairo, Egypt. Tumor promotion was induced by adding PB at a dose of 500 ppm in the drinking water according to (Finnberg et al., 1999).

\section{Extraction and purification of lycopene:}

Lycopene was extracted from tomato processing wastes or pomace obtained from tomato sauce processing line in the factory of Kaha. Extraction with diethylether, concentration and purification of lycopene were performed using the method described by Kew and Berry (1970). The purity of lycopene reached $95 \%$ as assessed by high performance liquid chromatography (HPLC).

\section{Experimental design:}

The experimental animals were divided into four groups, each of ten rats as follows:

1. Control group of rats only given standard casein diet.

2. Group of rats i.p. injected 5 times with DEN at doses of $200 \mathrm{mg} / \mathrm{kg}$ b.w., one dose every two days.

3. Group of rats orally given $0.12 \mathrm{mg}$ of lycopene daily according to Narisawa $e t$ al. (1996) till the end of the experimental period.

4. Group of rats orally given $0.12 \mathrm{mg}$ of lycopene daily starting 7 days before DEN injection and still continued till the end of the experimental period.

Rats in group 2 and 4 were treated with PB (500 ppm in the drinking water) starting with the first injection of DEN and continued till the end of the experimental period. At the end of the treatment time, blood samples were collected after $12 \mathrm{~h}$. from fasting rat groups using the orbital sinus technique, then centrifuged at 3000 r.p.m. for 10 minutes. The clear supernatant serum was frozen at $20^{\circ} \mathrm{C}$ for the subsequent analysis.

\section{Extraction of cytosol from liver tissue:}

Liver was dissected out, then $0.5 \mathrm{~g}$ liver tissue was homogenated in $10 \mathrm{ml}$ of distilled water at $4^{\circ} \mathrm{C}$. The homogenate was centrifuged for 20 minutes at $4^{\circ} \mathrm{C}$ at 12000 r.p.m. The supernatant was taken and recentrifuged for $30 \mathrm{~min}$ at 15000 r.p.m. at
$4{ }^{\circ} \mathrm{C}$. Collected sera and cytosol were used for the determination of $\alpha$-L-Fucosidase and MMPs enzymes.

\section{Biochemical methods: $\alpha$-L-Fucosidase enzyme:}

Activity levels of $\alpha$-L-fucosidase enzyme in serum and cytosol were assayed by the modification of the method according to Zielke et al.(1972). $10 \mu \mathrm{L}$ of serum were added to $50 \mu \mathrm{L}$ of the substrate mixture, p-nitropheny L- $\alpha$-Fucopyranoside dissolved in phosphate buffer (PHS) and incubated for 1 hour at $37^{\circ} \mathrm{C}$. The reaction was stopped by adding $3.5 \mathrm{ml}$ of stop buffer pH 10.5 (115 mM sodium carbonate, 15 $\mathrm{mM}$ glycine and $7.5 \mathrm{mM}$ sodium chloride). Blanks were prepared in the same way but the incubation step was omitted. Absorbance of $\mathrm{p}$ nitrophenol was read at $400 \mathrm{~nm}$. The change in absorbance of the liberated pnitrophenol was directly proportional to the activity of $\alpha$-L-fucosidase enzyme.

\section{MMPs enzyme:}

Gelatin zymography: The gelatinolytic activity of MMPs was evaluated according to the method described by (Nagata et al., 1976). Serum and cytosol (40 $\mu \mathrm{g}$ of total protein per lane) underwent electrophoresis $10 \%$ polyacrylamide gels containing $10 \%$ sodium dodecyl sulfate (SDS) and gelatin type $B(1 \mathrm{mg} / \mathrm{ml})$ under non- reducing and without boiling. After electrophoresis, the SDS was removed from the gels by washing with $2.5 \%$ Triton X-100 at room temperature, and the gels were incubated overnight at $37^{\circ} \mathrm{C}$ with gentle shaking in

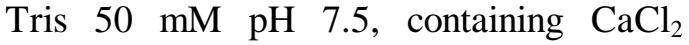
$10 \mathrm{mM}$ and $\mathrm{ZnCl}_{2} 1 \mathrm{mM}$ in order to activate metalloproteinases substrate digestion. After staining with coomassie blue and destaining, the final gel had a uniformly blue background except in regions to which MMPs and collagenase (standard) have migrated and activated the development of lysis bands.

Densitometric Scans: Band intensity was quantified by means of densitometric scanning using a system incorporating a vedio camera and a computer analysis package, the results were calculated as $\mu \mathrm{g}$ 
collagenase for MMPs/40 $\mu \mathrm{g}$ total protein from serum and cytosol.

\section{Histological study:}

Specimens from liver were fixed immediately in $10 \%$ neutral buffered formalin, dehydrated in different grades of alcohol, cleared in xylol, embedded in paraffin wax, sectioned at 4-6 $\mu$ thick and stained with Haematoxylin and Eosin (Bancroft et al., 1996) and examined microscopically.

\section{Statistical analysis:}

The results were statistically evaluated using Student's " $t$ " test (Snedecor and Cochran, 1989).

\section{Results:}

Table(1):Serum and cytosol $\alpha$-Lfucosidase enzyme activity in different groups of animals $(\mu \mathrm{mol}$ $\mathrm{PNP} / \mathrm{hr} / \mathrm{L})$.

\begin{tabular}{|c|c|c|}
\hline $\begin{array}{c}\text { Experimental } \\
\text { groups }\end{array}$ & Serum & Cytosol \\
\hline Control & $2.26 \pm 0.19$ & $2.63 \pm 0.23$ \\
& $(100 \%)$ & $(100 \%)$ \\
\hline DEN & $2.82 \pm 0.02^{* a}$ & $3.19 \pm 0.09^{* a}$ \\
& $(124.8 \%)$ & $(121.3 \%)$ \\
\hline Lycopene & $2.19 \pm 0.14$ & $2.52 \pm 0.13$ \\
& $(97.0 \%)$ & $(95.8 \%)$ \\
\hline Lycopene + & $2.33 \pm 0.17$ & $2.74 \pm 0.19$ \\
DEN & $(103.1 \%)$ & $(104.2 \%)$ \\
\hline
\end{tabular}

-Each value represents the mean of 10 rats \pm SE.

- * Significant difference from control at $\mathrm{P}<0.05$

and $* *$ highly significant difference at $\mathrm{P}<0.01$.

-a:Significant difference between DEN and lycopene + DEN groups.

The activity levels of $\alpha$-L-fucosidase enzyme in the serum and cytosol of rats receiving DEN and/or lycopene are presented in Table (1). Injection of DEN to rats induced significant increase in $\alpha-\mathrm{L}$ fucosidase enzyme activity in both serum and cytosol as compared with the control group, the percentage of increase from control equal to 124.8 and $121.3 \%$ in serum and cytosol respectively.

The intubation of lycopene induced slightly non-significant decrease in the enzyme levels comparing to the control group in both serum and cytosol. Administration of lycopene prior to DEN injection resulting in less pronounced changes than those recorded in rats injected with DEN, there were non-significant changes between (Lycopene + DEN) and control groups in both serum and cytosol. Meanwhile, there were significant differences between (Lycopene + DEN) group as compared with the DEN group in both serum and cytosol.

Results in Table (2) showed measurement of MMPs activity levels in serum and cytosol in male albino rats, to investigate the preneoplastic lesions growth in liver induced by DEN. The MMPs activity was resolved into its active form $(92 \mathrm{KDa})$ of bands that appeared in the gel Fig (1\&2) for cytosol and serum, respectively. The results indicated that injection with DEN caused a marked significant elevation in MMPs enzyme activity in cytosol and highly significant difference in serum as compared with the control group. The percent changes of increase from control in DEN group were 145 and $135.4 \%$ in serum and cytosol respectively.

\section{Table (2): Serum and cytosol MMPs enzyme activity in different groups of animals.}

\begin{tabular}{|c|c|c|}
\hline $\begin{array}{c}\text { Experimental } \\
\text { groups }\end{array}$ & Serum & Cytosol \\
\hline Control & $\begin{array}{c}10.75 \pm 0.8 \\
(100 \%)\end{array}$ & $\begin{array}{c}5.17 \pm 0.39 \\
(100 \%)\end{array}$ \\
\hline DEN & $15.59 \pm 1.2^{* * a}$ & $7.0 \pm 0.5^{* a}$ \\
& $(145 \%)$ & $(135.4 \%)$ \\
\hline Lycopene & $12.26 \pm 1.19$ & $6.03 \pm 0.74$ \\
& $(114 \%)$ & $(116.6 \%)$ \\
\hline Lycopene + & $12.49 \pm 1.08$ & $5.48 \pm 0.47$ \\
DEN & $(116.2 \%)$ & $(105.9 \%)$ \\
\hline
\end{tabular}

-MMPs expressed as $\mu \mathrm{g}$ collagenase $/ 40 \mu \mathrm{g}$ total protein.

-Each value represents the mean of 10 rats \pm SE

- * Significant difference from control at $\mathrm{P}<0.05$ and ** highly significant difference at $\mathrm{P}<0.01$.

a: Significant difference between DEN and lycopene + DEN groups.

Administration of lycopene caused non-significant changes in the enzyme activity comparing to the control group in both serum and cytosol. Ingestion of lycopene pre-DEN injection revealed significant amelioration effects, there were significant differences between DEN and lycopene + DEN groups in both serum and cytosol. Meanwhile, the changes between control and lycopene + DEN groups were non-significant in both serum and cytosol. 
Inas Z.A. Abdallah and Hala A.H. Khattab
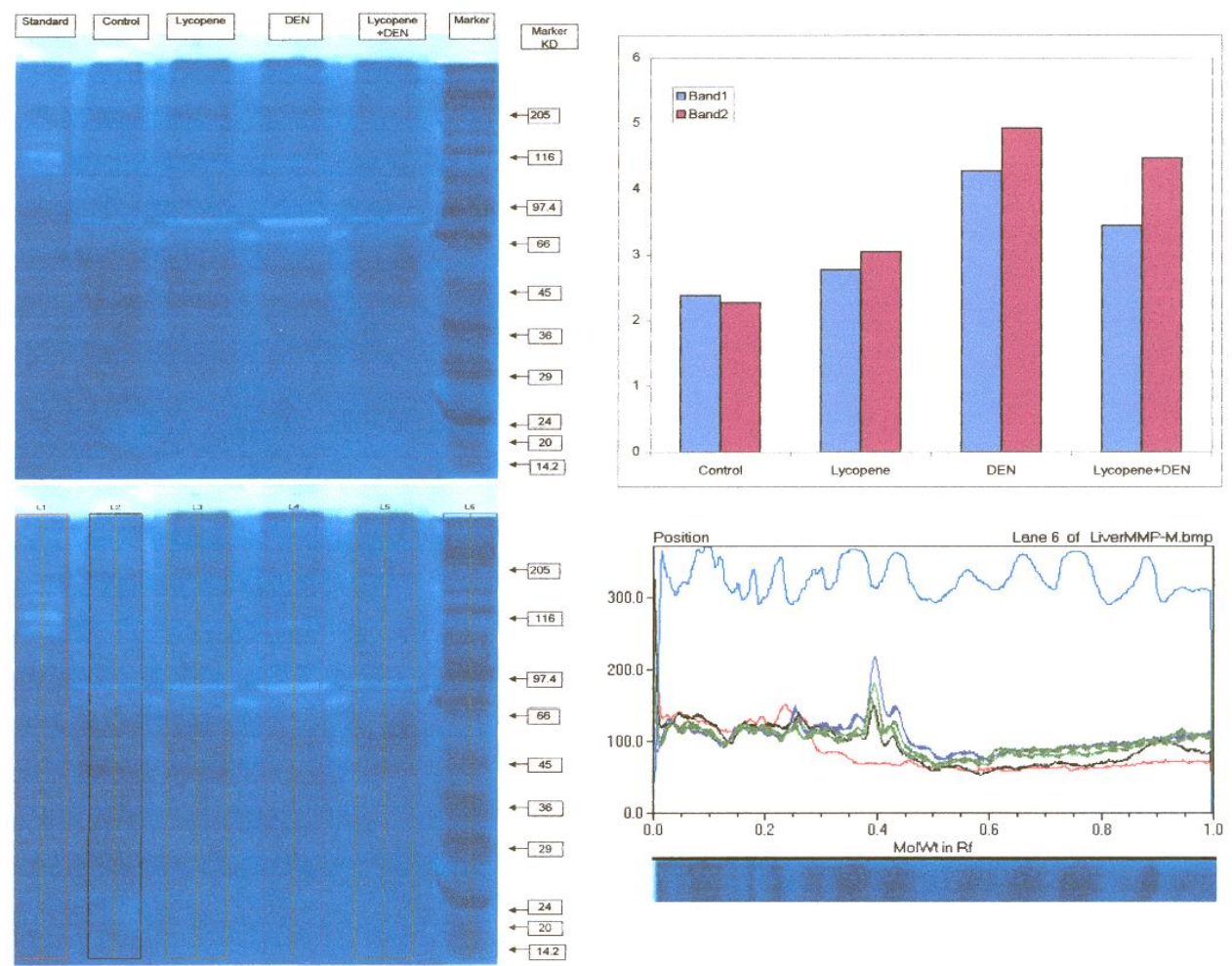

Fig (1): Geiatin zymography of SDS PAGE for rats liver MMPS activity levels
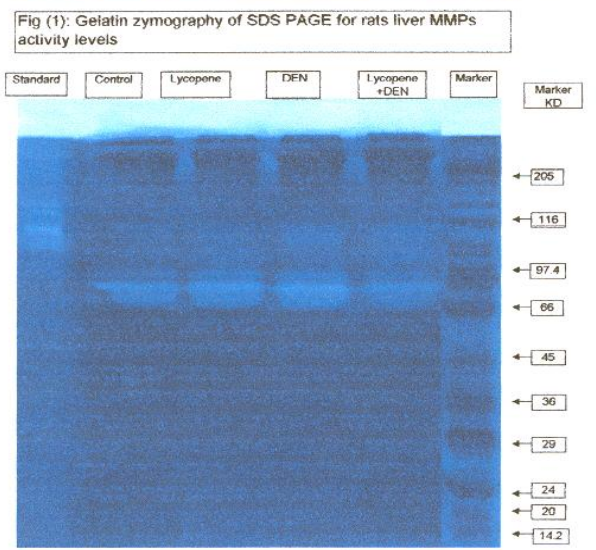

Fig (1): Densitometric scans of SDS PAGE for rats liver MMPS activity levels
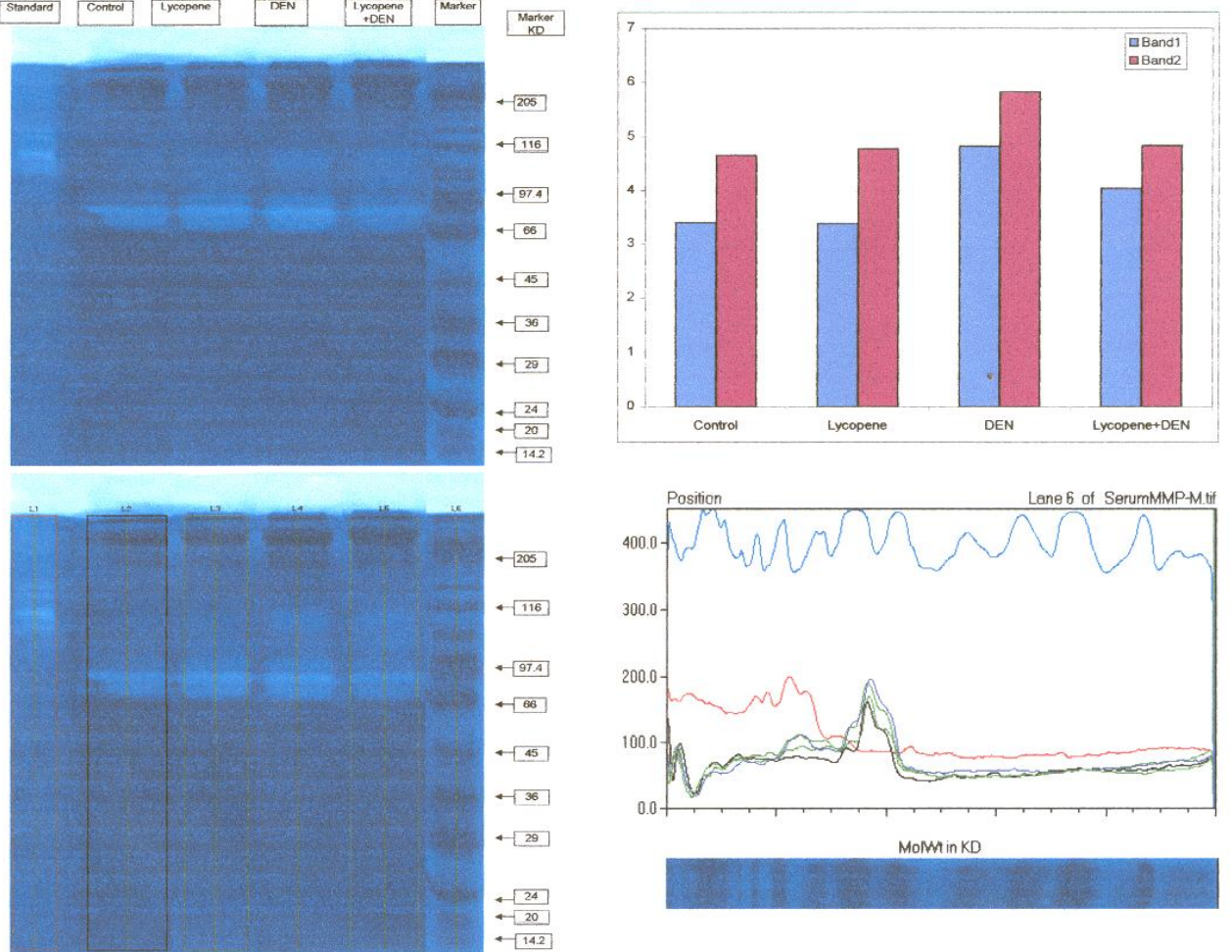

Fig (2): Gelatin zymography of SDS PAGE for rats serum MMPS

Fig (2): Densitometric scans of SDS PAGE for rats serum MMPS activity ievels 
Histopathological results:

Microscopical examination of liver from control rats showing no histological changes (Fig. 3). On the other hand, examined liver from rats treated with (DEN) revealed severe and deleterious changes, those changes confined as multiple hyperplastic and anaplastic hepatocellular nodules surrounded with thin layer of fibroplastic cells, absence of the central veins. The nodules made up of cells that resemble liver cells, but were anaplastic, habhazardly arranged and vary in their size and staining features (some clear cells with fainty cytoplasm and other cells deeply stained) (Figs. 4 and 5). Mitosis and enlarged nuclei

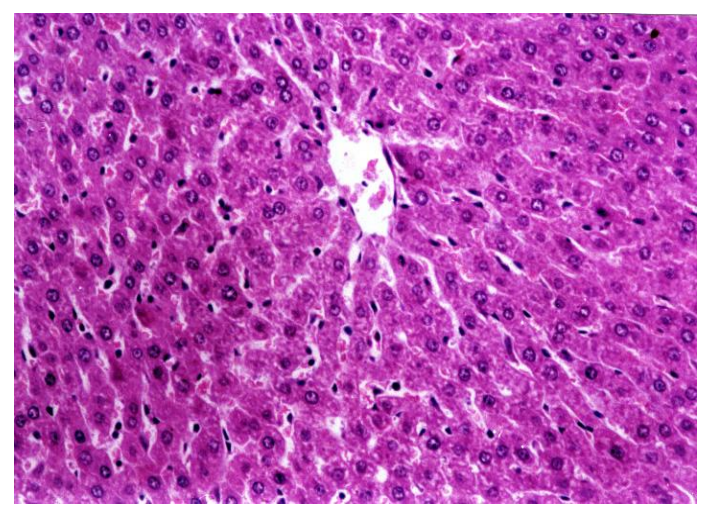

Fig. (3): Liver of control, non-treated rats showing no histological changes.

(H \&E stain X 200)

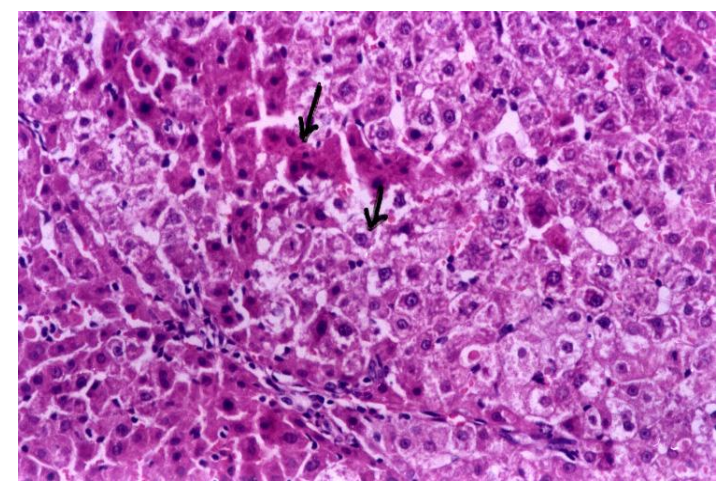

Fig. (5): Liver of rats treated with (DEN) showing mixed cell foci (clear cell hepatocytes and basophilic cell hepatocytes), notice the habhazardly arranged hepatocytes.

(H \& E stain X 200) were also seen in the examined cases. The portal tract showed irregularsied sized bile ductuoles, lined with cuboidal epithelium, which resembles epithelium of intrahepatic bile ducts, Less differentiated cells appear in solid masses with large nuclei and mitotic figures also seen. In some cases, proliferation of connective tissue (desmoplasia) and inflammatory cells infiltrations were also observed (Figs. 6 and 7).

Hepatic haemorrhages associated with necrosis were noticed in the examined sections (Fig. 8). Liver of rats treated with lycopene showed normal histological structure (Fig. 9). Liver of rats treated with combined lycopene + DEN also showed no histopathological changes (Figs. 10 and 11).

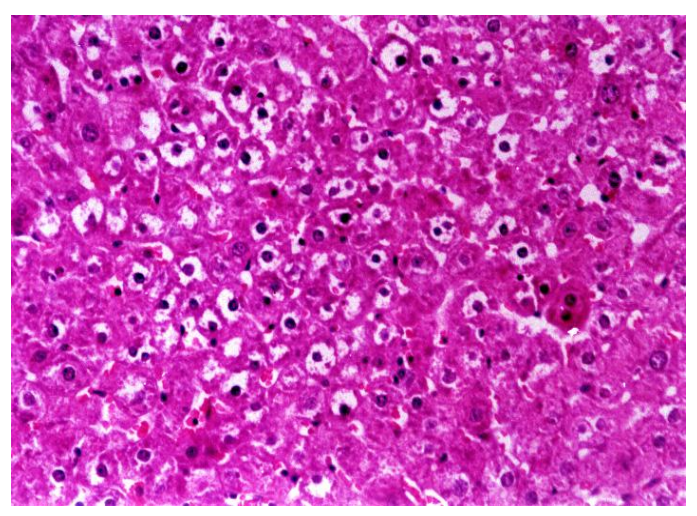

Fig. (4): Liver of rats treated with (DEN) showing proliferated hyperplastic hepatocellular and analplastic nodule (no central vein and the hepatocytes vary in their size and staining affinity) . $\quad$ (H \& E stain $X$ 200)

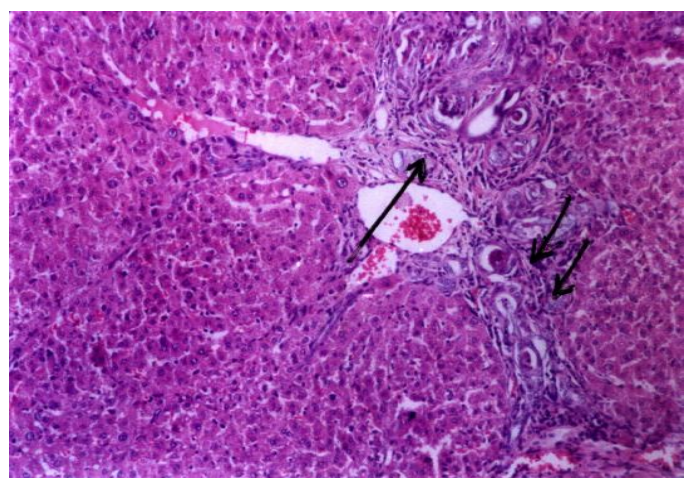

Fig. (6) : Liver of rats treated with (DEN) showing proliferated irregular sized bile ductuoles as well as desmoplasia and inflammatory cells infiltration (arrows)

(H \& E stain X 100) 


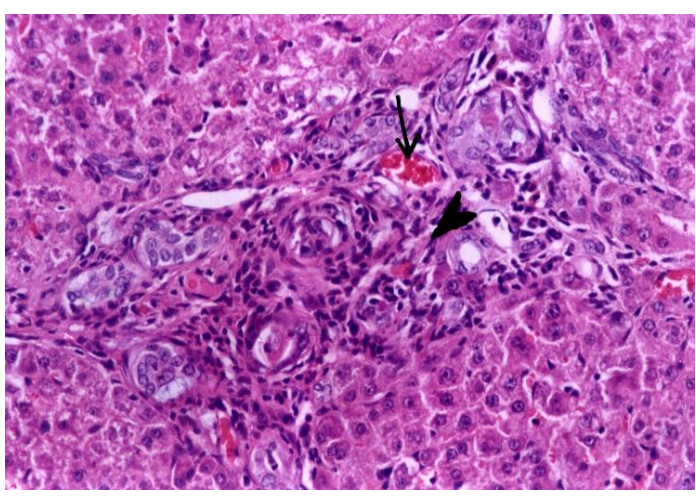

Fig. (7): Liver of rats treatead with (DEN) showing proliferated bile ducts, the cells undifferentiated and form solid masses (arrow) as well as desmoplasia associated with inflammatory cells infiltration (arrow head).

(H \& E X 200)

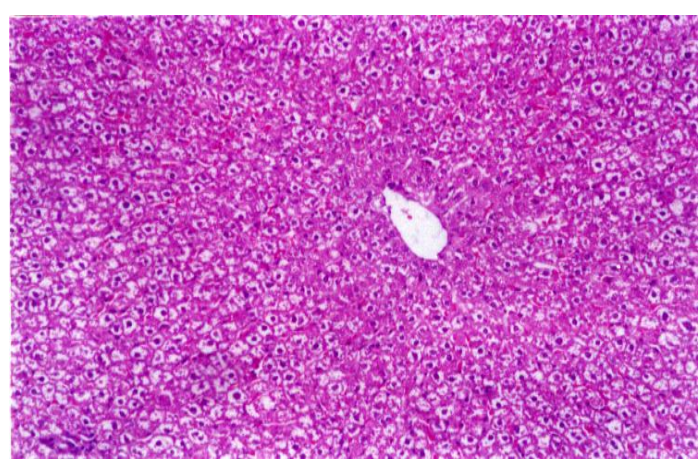

Fig. (9): Liver of rats treated with (Lycopene) showing normal histological structure. (H \& E stain X 100).

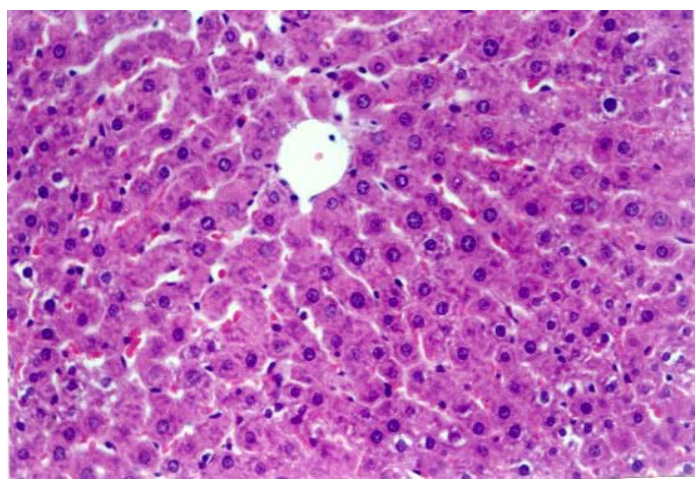

Fig. (11): Liver of rats treated with combined (Lycopene + DEN) showing no histopathological changes.

\section{Discussion}

H \& E stain X 200).

It is well known that DEN is a potent hepatocarinogen. Chuang et al. (2000) found that DEN induced $\mathrm{HCC}$ formation

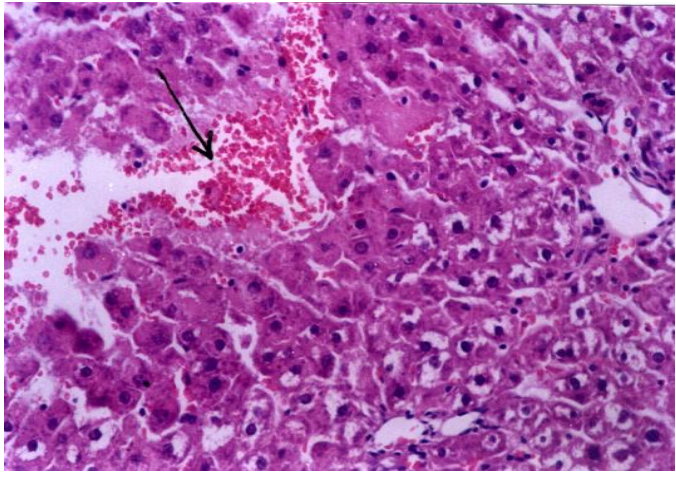

Fig. (8) : Liver of rats treated with (DEN) showing focal hepatic haemorrhages and necrosis (arrow).

(H \& E stain X 200)

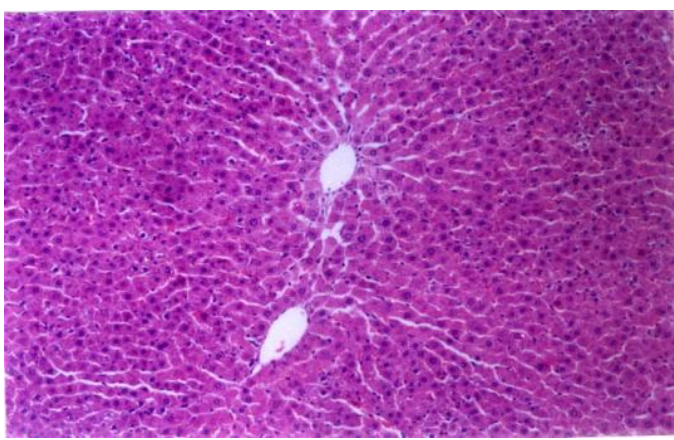

Fig. (10): Liver of rats treated with (Lycopene +DEN) showing no histopathological changes.

(H \& E X 100)

in the mouse. The tumor initiation was achieved by a single i.p. injection of DEN (200 mg/kg b.w.). Nitroseamines are very common in processed foods such as bacon, dried and canned vegetables, beer and in cigar smoke. Humans are exposed to nitrosamines in several ways, and are especially effective by the oral route (Tricker and preussmann, 1991). Rao and Agarwal (1999) reported the significant role of lycopene rich foods in prevention of chronic diseases and cancers in cell culture, animal experiments and clinics.

In the present study, DEN treated group showed a marked significant increase in $\alpha$-L-fucosidase enzyme activity levels in both serum and cytosol as compared with the control group. 
This finding was in agreement with the result of El-Houseini et al. (2001) who reported that in patients with $\mathrm{HCC}, \alpha$-Lfucosidase enzyme levels were signifycantly higher and correlated to the size of the tumor and the histopathologic grades. The increase in $\alpha$-L-fucosidase may be attributed to increased synthesis of proteins by tumor with a consequent increase in fucose turnover (Deugnier, 1984). This finding is very important because it is well known that DEN confers hepatocarcinogenic action by its metabolic conversion to a reactive ethylating agent, which can alkylate cellular DNA (Bartsch et al., 1989). DEN-activating P450 isozyme, markedly increased and may play a role in inflammation related tumor initiation. Inflammation also activates many proliferation factors and cytokines, which are involved in tumor promotion (Moshage, 1997).

The present study also revealed that group of rats administered lycopene prior to DEN injection showed a slight non-significant increase and significant elevation in $\alpha$ L-fucosidase enzyme activity levels in both serum and cytosol as compared with the control and DEN groups, respectively. In vitro studies have shown a tumor supperssive activity of lycopene. Huang et al. (1997) stated that lycopene as antioxidant suppressed a severe hepatic inflammatory reaction induced by high dose of DEN in the rat. The mechanism for cancer preventing action of lycopene observed in animal models may involve antioxidant activity, stimulation of gap junction intercellular communication, induction of detoxifying enzymes, and inhibition of cellular proliferation (Cooper et al., 1999).

The present results showed clear significant elevation in MMPs enzyme activity in both serum and cytosol of DEN group as compared with the control group. This was in agreement with Nakajima et al. (1993) who reported elevated level of MMPs in serum and plasma of animals bearing experimental tumors. Moreover, Moses et al. (1998) reported that elevated production of MMPs enzyme by cancer cells and tumor stroma correlates with the malignant or metastatic phenotype. Overproduction of MMPs by a tumor communicating with the vascular and lymphatic systems might result in increased levels of MMPs activity in other body fluids, such as blood or urine.

On the other hand, MMPs play an important role in the tissue remodeling of the liver, these enzymes regulate the proliferation and migration of hepatocytes (Watanabe et al., 2003). The early stage of angiogenesis is characterized by proteolytic degradation of basement membrane that involves active serines proteases and MMPs, a family of proteases with specificity for matrix molecules. It consists of collagenases, which cleaves collagen types I, II and III. These collagen fragments are further degraded by the gelatinases, $72 \mathrm{KDa}$ gelatinase A (MMP-2) or $92 \mathrm{KDa}$ gelatinase B (MMP-9) and by stromelysins (Nagase, 1996). The stage of tumor progression is positively correlated with the expression of MMP family members. Changes in MMP levels can markedly affect the invasive behavior of tumor cells and their ability to metastasize in experimental animal models (Coussens et al., 2003).

In the obtained results, there was significant descent in MMPs enzyme activity in both serum and cytosol of lycopene + DEN group as compared with the DEN group. This finding was explained by Giovannucci (1999) and Mucci et al. (2001) who reported that lycopene may protect lipids, nucleic acids and proteins from oxidative damage that could otherwise lead to cancer. It is also possible that lycopene enhances cellular differentiation, inhibits cell proliferation, maintains intercellular communication, interacts with growth factors, or influences carcinogenesis through other mechanisms. Moreover, lycopene could influence the cancer cascade by regulating gene functions, modulating hormone status, carcinogen metabolism, immune status and angiogenesis (Folkman, 1995, Kobayashi et al., 1996 and Agarwal and Rao, 2000).

The histological investigation of liver sections in rats injected with DEN revealed severe and deleterious changes varied from the presence of multiple hyperplastic and anaplastic nodules surrounded with thin layer of fibroblastic cells, desmoplasia and inflamm- 
atory cells infiltrations, to focal hepatic haemorrhages and necrosis. These findings were in coincidence with the observations of Chuang et al. (2000) who found that DEN-induced hepatic nodules in rats fulfilled the histological criteria of HCC.

Moreover, Finnberg et al. (1999) reported that DEN treated rats developed enzyme altered foci (EAF) in rat liver and the longer the period of treatment the larger the size of the EAF. They found that many lesions in rats receiving DEN for 10-12 weeks had probably reached the point when conversion to a tumor was imminent. Deal et al. (1989) stated also that DEN may induce cytotoxicity and apoptosis. A progressive increase in replication of hepatocytes has been observed in response to increasing doses of DEN. It is a potent hepatocarcinogen, principally in the first step of neoplastic transformation (Cortinovis et al., 1991). Lijinsky (1987) stated that initiation is the first damage suffered by the cell, if such damage is permanent it could lead to cancer. DEN has a great capacity for causing permanent genotoxic damage to cells, so it is an efficient cancer initiator.

On the other hand, DEN inducing cell death or a stop in the cell cycle in surrounding hepatocytes and by inducing adaptation to such effect, i.e., down regulation of P53 expression. The low levels of DEN may not down-regulate P53 expression. At high doses, it might become a dominating mechanism for accumulating mutations (Williams et al., 1996).

Histological examination of liver sections of rats treated with lycopene confirmed the protective effect of lycopene in relation to liver structure. Concerning liver of rats treated with combined (Lycopene + DEN) showed no histopathological changes. This finding was coincided with the finding of Matushima-Nishiwaki et al. (1995). They recorded the effective role of lycopene in protecting against microcystin-LR-induced liver tumors in mouse hepatocytes. They suggested that lycopene may inhibit tumor promotion by suppressing the hyperphosphorylation of cellular proteins.

Furthermore, He et al. (1997) found that the intubation of rats with a carotenoidrich extract from tomato paste decreased the preneoplastic foci induced by aflatoxin during the initiation period, suggesting a beneficial role of lycopene in the early stages of hepatocarcinogenesis. Astorg et al. (1997) also found a decrease in the size of preneoplstic foci in rats liver as well as in the fraction of liver volume occupied after lycopene supplementation, but not after $\beta$-carotene, cantaxanthin and astaxanthin supplementation. This finding in the lycopene + DEN group may be attributed to the ability of lycopene to cause a reversible inhibition of cell transformation initiated by carcinogens. This activity was correlated with the ability of lycopene to upregulate gap junction communication by increasing the gene expression of connexin 43 (Zhang et al., 1992), a component of the gap junction structure. Loss of gap junctional communication may be important for malignant transformation, and its restoration may reverse the malignant process.

In conclusion, the present data indicated the inhibitory effect of lycopene, the natural extract from tomato pomace on DEN induced hepatocarcinogenesis in rats which is likely to be related to the detoxification of the carcinogen through inhibition or by induction of enzymes. Alternatively, lycopene may have a role in interfering with carcinogen DENbinding to elicit its antitumorigenic response. Otherwise, lycopene could play a role in repairing genetic lesions or by reinforcing immune surveillance mechanisms.

Acknowledgement: The authors would like to thanks Prof. Dr. Motawa E. El-Houseini, Cancer Biology Dept., National Cancer Institute, Cairo University, for his kind cooperations, especially in the practical part of this study. Thanks also go to Prof. Dr. Hamed S. Hamed, Professor of food technology, Food Technology Dept., Food Technology Research Institute, Agric. Res. Center, Giza, for his help in lycopene extraction. Finally, full gratitude extended to Dr. Kawkab A. Ahmed, Lecture of pathology, Faculty of Veterinary Medicine, Cairo University for her help to carry out histopathological study of this work.

\section{References:}

1. Agarwal, S. and Rao,A.V. (2000):Tomato lycopene and its role in human 
health and chronic disease. Canadian Medical Association J., 163(6): 739-744.

2. Ames,B.N. and Gold,L.S. (1990):- Too many rodent carcinogens: mitogenesis increases mutagenesis. Sci., 249:970-971.

3. Astorg,P., Gradelet,S. Berges, R. and Suschetet,M. (1997):- Dietary lycopene decreases the initiation of liver preneoplastic foci by diethylnitrosamine in the rat. Nutr. Cancer, 29:60.

4. Bancroft,D., Stevens,A. and Turmer,R. (1996):- Theory and practice of histological technique, $4^{\text {th }}$ Ed, Churchill Living Stone, Edinburgh, London, Melbourne.

5. Bartsch,H., Hictanen,E. and Malavelle,C. (1989):- Carcinogenic nitrosoamines: free radical aspects of their action, Free Red. Biol. Med., 71: 637-643.

6. Chhabra,S.K., Souliotis,V.L., Kyrtopoulos,S.A. and Anderson, L.M. (1996):- Nitrosamines, alcohol, and gastrointestinal tract cancer: recent epidemiology and experimentation. In vivo, 10: 265-284.

7. Chuang,S.E., Kuo,M.L., Hsu,C.H., Chen,C. R., Lin,J.K., Lai,G.M., Hsieh,C.Y. and Cheng, A.L. (2000):- Curcumin-containing diet inhibits diethylnitrosamine-induced murine hepatocarcinogenesis. Carcinogenesis, 21 (2):331335.

8. Clinton,S.K. (1998):- Lycopene: chemistry, biology, and implications for human health and disease. Nutrition Reviews, 56(2): 35-51.

9. Cooper,D., Eldrigde,A.L. and Peters,J.C. (1999): Dietary carotenoids and lung cancer: a review of recent research. Nutr. Rev., 57: 133145.

10. Cortinovis,C., Klimek,F. and Nogueira,E. (1991):- Rat hepatocarcinogenesis induced by $\mathrm{N}$-nitroso diethylamine and $\mathrm{N}$-nitrosopholine continuously administered at low doses form basophilic areas of hepatocytes to hepatocellular tumors. American Journal of Physiology, 139: 157-1171.

11. Coussens,L.M. and Werb,Z. (1996):Matrix metalloproteianses and the development of cancer. Chem. Biol., 3: 895-904.

12. Coussens,L.M., Fingleton,B. and Matrisian, L.M. (2003):- Matrix metalloproteinase inhibitors and Cancer. Trials and Tribulations. Science. 295(5564): 2387.

13. Deal,F.H., Richardson,F.C. and Swenberg, J.A. (1989):- Dose response of hepatocyte replication in rats following continuous exposure to diethylnitrosomine. Cancer Res., 49: 6985-6988.
14. Deugnier,Y. (1984):- Serum $\alpha$-L-Fucosidase: A new marker for the diagnosis of primary hepatic Carcinoma. Hepatol., 4:889-892.

15. El-Houseini,M.E., Amer,M.A., El-Din,A.H., El-Sherbiny, M. and Hussein,T.D. (2001):Serum $\alpha$-L-Fucosidase enzyme activity as a marker for hepatocellular carcinoma: Comparison with AFP using ROC analysis. $\mathrm{J}$ of Egyptian National Cancer Institute, 13(4): 277-283.

16. Finnberg,N., Stenius,U. and Hogberg,J. (1999):- Xenobiotics modulate the P53 response to DNA damage in preneoplastic enzyme-altered foci in rat liver; effects of diethylnitrosamine and Phenobarbital. Toxicological Sciences, 54:95-103.

17. Folkman,J. (1995):- Clinical application of research on angiogenesis. N. Engl. J. Med., 333:1757-1763.

18. Franceschi,S., Bidoli,E., La Vecchia,C., Talamini,R., D'Avanzo, B. and Negri, E. (1994):-Tomatoes and risk of digestive-tract cancers. Int. J. Cancer, 59: 181-184.

19. Freidman,S.L. (1993):- The cellular basis of hepatic fibrosis. New Eng. J. Med., 328: 1828-1835.

20. Giardina,M.G.,Matarazzo,M., Morante,R., Lucariello,A., Varriale,A., Guardasole,V. and DeMarco,G. (1998):- Serum $\alpha$-LFucosidase activity and early detection of hepatocellular carcinoma: a prospective study of patients with cirrhosis. Cancer, 83(12): 2468-2474.

21. Giovannucci,E.(1999):-Tomatoes, tomatobased products, lycopene, and cancer: review of the epidemiologic literature. J Natl Cancer Inst, 91: 317-331.

22. Giovannucci,E., Ascherio,A., Rimm,E.B., Stampfer ,M.J., Colditz,G.A. and Willet,W.C. (1995):- Intake of carotenoids and retinol in relation to risk of prostate cancer. J. Natl. Cancer Inst., 87:1767-1776.

23. He,Y., Root,M.M., Parker,R.S. and Campbell, T.C. (1997):- Effect of carotenoid-rich food extracts on the development of preneoplastic lesions in rat liver and on in vivo and in vitro antioxidant Satus. Nutr. Cancer, 27(3): 238.

24. Helzlsouer,K.J., Comstock,G.W. and Morris, J.S. (1989):- Selenium, lycopene, $\alpha$-tocopherol, $\beta$-carotene, retinal, and subsequent bladder cancer. Cancer Res., 49: 6144-6148.

25. Huang,M.T., Newmark,H.L. and Frenkel, K. (1997):- Inhibitory effects of curcumin on tumorigenesis in mice. J. Cell. Biochem., 27 (Suppl.): 26-34. 
26. Ito,N., Imaida,K., Hirose,M. and Shirai, T. (1998):- Medium-term Bioassay for carcinogenicity of chemical mixtures. Environmental Health Perspectives, 106(6): 1331-1335.

27. Jen,K.L. and Yuan,S.H. (1994):- Hepatotoxic actions of dietary amines. Toxicology and Ecotoxicology News, 1:82-86.

28. Kew,T.J. and Berry,R.E. (1970):-Citrus product color enhancement using extracts of peel of different varieties. J. Food. Sci., 35:436-439.

29. Kobayashi,T., Lijima,K. and Mitamura, T. (1996):- Effect of lycopene, a carotenoid, on intrathymic $\mathrm{T}$ cell differentiation and peripheral $\mathrm{CD} 4 / \mathrm{CD} 8$ ration in a high mammary tumor strain of SHN retired mice. Anticancer. Drugs (England), 7: 195198.

30. Kuo,M.L., Shen,S.C. Yang,C.H. Chuang, S.E., Cheng,A.L. and Huang,T.S. (1998):BCL-2-prevents topoisomerase II inhibitor GL331-induced apoptosis is mediated by down regulation of poly (ADP-ribose) polymerase activity. Oncogene, 17:22252234.

31. Levy,J., Bosin,E., Feldman,B., Giat, Y, Miinster,A., Danilenko,M. and Sharoni, Y. (1995):- Lycopene is a more potent inhibitor of human cancer cell proliferation than either $\alpha$ carotene or $\beta$-carotene. Nutr. Cancer, 24:257266.

32. Lewis,D.F.V., Brantom,P.G., Loannides,C., Walker,R. and Parke,D.V.(1997):- Nitrosomine Carcinogenesis: Rodent assays, quantitative structure activity relationships, and human risk assessment. Drug Metab. Rev., 29: 1055-1078.

33. Lijinsky,I. (1987):- Structure activity relations in carcinogenesis by N-nitro compounds. Cancer Methods Rev., 5:301-356.

34. Lin,K. and Ho,Y. (1994):- Hepatotoxic actions of dietary amines. Toxicology and Ecotoxicology News, 1:82-86.

35. Magee,P.N. (1996):- Nitrosamines and human cancer Introduction and overview. European Journal of Cancer Prevention, 5: 7-10.

36. Mathews-Roth, M. M., Welankiwar,S., Sehgal, P.K., Lausen,N.C.G., Russett,M. and Krinsky,N.I. (1990):- J.Nutr., 120:12051213.

37. Matsushima-Nishiwaki,R., Shidoji,Y., Nishiwaki,S., Yamada,T. Moriwaki,H. and Muto,Y. (1995):- Suppression by carotenoids of microcystin-induced morphological changes in mouse hepatocytes. Lipids, 30:1029.

38. Moses,M.A., Wiederschain,D., Loughlin, K.R., Zurakowski, D.,Lamb,C.C. and
Freeman, M.R. (1998):- Increased incidence of Matrix metalloproteinases in urine of cancer patients. Cancer Res., 58(1): 1395-1399.

39. Moshage,H. (1997):- Cytokines and the hepatic acute phase response. J. Pathol., 181: 257-266.

40. Mucci,L.A., Tamimi,R. and Lagiou,P. (2001):- Are dietary influences on the risk of prostate cancer mediated through the insulin-like growth factor system. BJU Int., 87: 814-820.

41. Nagase,H. (1996):- Matrix metalloproteinases. In zinc Metalloproteases in Health and disease. Hooper, N.M. ed., Taylor and Francis, London, P. 153-204.

42. Nagata, K., Takahashi,E., Saito,M., Ono,J., Kuboyama, M. and Ogasa,K. (1976): -Differentiation of a cell line of mouse myeloid leukemia 1. simultaneous induction of lysosomal enzyme activities and phagocytosis. Exp. Cell Res., 100: 322328

43. Nakae,D., Kobayashi,Y., Akai,H., Andoh,N., Satob,H., Ohashi,K., Tsutsumi,M. and Konishi,Y. (1997):- Involvement of 8hydroxyguanine formation in the initiation of rat liver carcinogenesis by low-dose levels of $\mathrm{N}$ nitrosdiethylamine, Cancer Res., 57:1281-1287.

44. Nakajima,M., Welch,D.R., Wynn,D.M., Tsuruo,T. and Nicolson,G.L. (1993):Serum and plasma M, 92.000 progelatinase levels correlate with spontaneous metatasis of rat 13762 NF mammary adenocarcinoma. Cancer Res., 53: 5802-5807.

45. Narisawa,T., Fukaura, Y., Hasebe,M., Nomura,S., Oshima,S., Sakamoto,H. Inakuma,T., Ishiguro,Y., Takayasu,J. and Nishino,H. (1998):- Prevention of $\mathrm{N}$-methylnitrosourea-induced colonic carcinogenesis in F344 rats by lycopene and tomato juice rich in lycopene. Jpn. J. Cancer Res., 89: 10031008.

46. Narisawa,T., Fukaura,Y., Hasebe,M., Ito,M., Aizawa,R., Murakoshi,M. Uemura,S., Khachik,F. and Nishino,H. (1996):- Inhibitory effects of natural carotenoid, $\alpha$ Carotene, $\beta$-Carotene, lycopene and lutein, on colonic aberrant crypt foci formation in rats. Cancer Lett., 107:137-142.

47. Okajima,E., Tsutsumi,M., Ozono,S., Akai,H., Denda,A., Nishino,H., Oshimas S., Sakamoto, H. and Konishi, Y. (1998):- Inhibitory effect of tomato juice on rat urinary bladder carcinogenesis after N-butyl-N-(4-hydroxybutyl) nitrosamine initiation. Jpn. J. Cancer Res., 89:22-26.

48. Osanai,M., Ogawa,K. and Lee,G.H. (1997):- Phenobarbital causes apoptosis in 
conditionally immortalized mouse hepotocytes depending on deregulated expression. Characterization of an unexpected effects. Cancer Res., 57: 2896-2903.

49. Pateron, D., Ganne, T., Trinchet, J. C., Auroosseau,M.H., Mal,F. and Meicler,C. (1994):- Prospective study of screening for hepatocellular carcinoma in Caucasian patients with cirrhosis. J. Hepatol., 20:6571.

50. Pinzani,M., Marra, F. and Carloni,V (1998):- Signal transduction in hepatic stellate cells. Liver, 18:2-13.

51. Rao.A.V. and Agarwal, S. (1999):- Role of lycopene as antioxidant in the prevention of chronic diseases. Nutr. Res., 19: 305323.

52. Snedecor,G.W. and Cochron,W.G. (1989):- Statistical methods, $8^{\text {th }}$ ed., Lowa State Univ. Press, Ames, Lowa, USA.

53. Stahl, W. and Sies, H. (1996):- Lycopene: a biologically important carotenoid for humans. Arch. Biochem. Biophys., 336:1-9.

54. Stahl, W.,Schwarz,W., Sundquist,A.R. and Sies, H. (1992):- Cis-trans isomers of lycopene and $\beta$-carotene in human serum tissues. Arch. Biochem. Biophys., 294:173-177.

55. Tangkijvanich,P., Tosukhowong,P., Bunyongyod, P., Lertmaharit,S., Hanvivatvong,O. and Kullavanijaya, P. (1999):- $\alpha$-LFucosidase as a marker of hepatocellular carcinoma in Thailand Southeast Asian. J. Trop. Med. Public. Health, 30(1): 110-114.

56. Tanumihardjo,S.A., Furr,H.C., AmedeeManesme,O. and Olson,J.A. (1990):- Int. J. Vitamin Nutr. Res., 60: 307-313.

57. Tricker,A.R. and Preussmann, R. (1991):- Carcinogenic N-nitrosamines in the diet: occurrence, formation, mechanisms, and carcinogenic potential. Mutation Research, 259:277-289.

58. Watanabe,Y., Haruyama,T. and Akaike,T. (2003):- Liver-derived matrix metallopro- teinase-9 (Gelatinase B) Recruits Progenitor cells from bone marrow into the blood circulation. Biol. Pharm. Bull., 26(4): 564-568.

59. Williams,G.K., Latropoulos,M.J., Wang, C.X and Gebhardt,R. (1996):Diethylnitrosamine exposure-responses for DNA damage, centrilobular cytotoxicity cell proliferation and carcinogenesis in rat liver exhibit some non-linearities. Carcinogensis, 17:2253-2258.

60. Wood,G.A. and Archer,M.C. (2001):- Matrix metalloproteinases-2 and 9 do not play a role in the growth of preneoplastic liver lesions in F344 rats. Exper. Biology and Medicine, 226(8): 799-803.

61. Yang,C.S. and Smith,T.J. (1996):Mechanisms of nitrosamine bioactivation and carcinogenesis. Advances in Experimental Medical Biology, 387: 385-394.

62. Zhang,L.X., Cooney,R.V. and Bertram,J.S. (1991):- Carotenoids enhance gap junctional communication and inhibit lipid peroxidation in G3H/10T1/2 cells: relationship to their cancer chemopreventive action. Carcinogenesis, 12: 2109-2114.

63. Zhang,L.X., Cooney,R.V. and Bertram,J.S. (1992):- Carotenoids up-regulate connexin 43 gene expression independent of their provitamin A or antioxidant properties, Cancer Res., 52: 5707.

64. Zhang,S., Tang,G., Russell,R.M., Mayzel, K.A., Stampfer,M.J., Willet,W.C. and Hunter,D.J. (1997):- Measurement of retinoids and carotenoids in breast adipose tissue and comparison of concentrations in breast cancer cases and control subjects. Am. J. Clin. Nutr., 66:626-632.

65. Zielke,K., Okada,S. and O'Brien,J. (1972):- Fucosidosis: diagnosis by serum assay of $\alpha$-L-Fucosidase. J. Lab. Clin. Med., 79:164169. 


\title{
الدور الوقائى للليكوبين ضد سرطان الكبد المستحدث بالداى إيثيل نيتروزأمين في فئران التجارب المبن
}

\author{
ايناس زيدان عبده عبد الله و هالة عبد الرحمن حسن خطاب

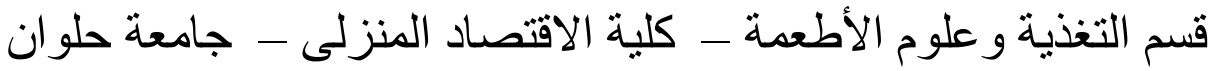

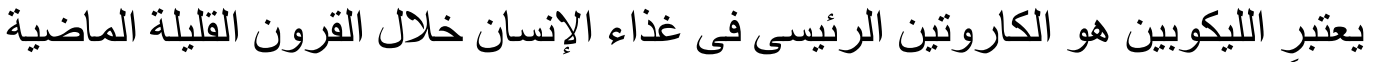

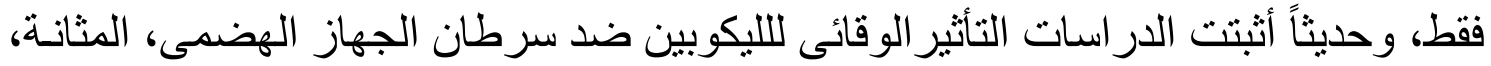

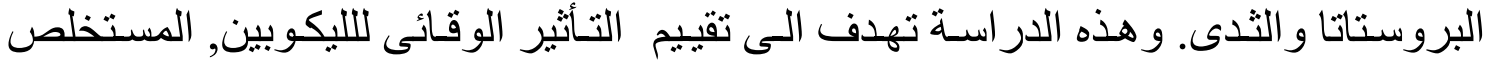

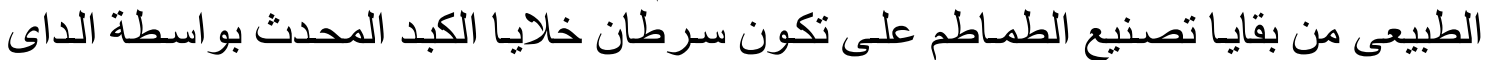

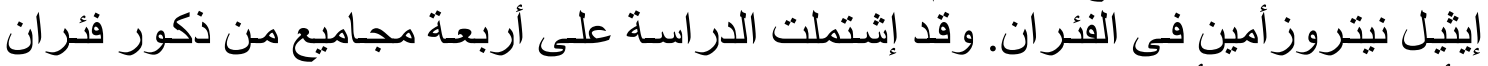

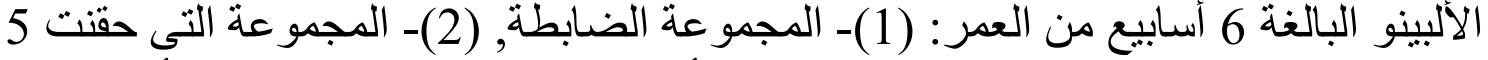

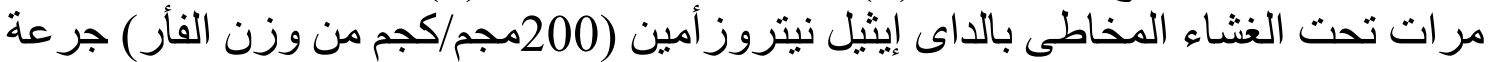

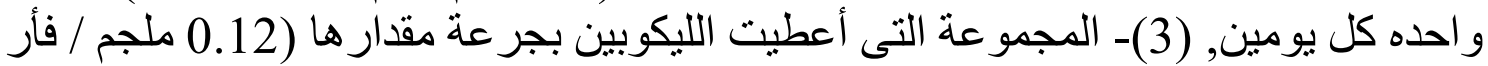

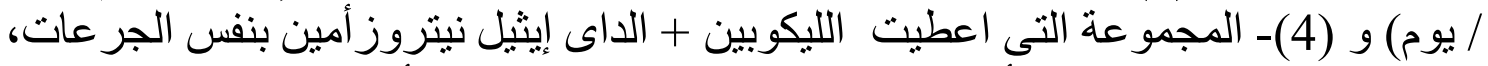

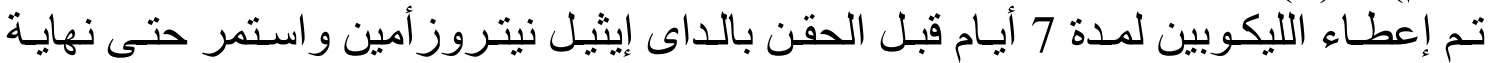

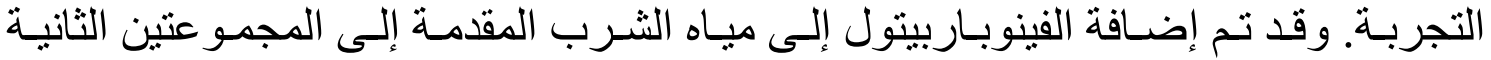

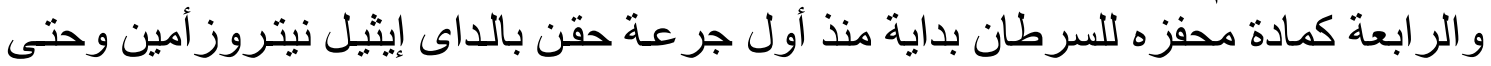

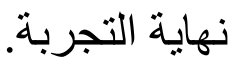

أوضحت النتائج أن الداى إيثيل نيتروز أمين أحدث تحفيز لتكونات سرطانية في خلايا الكبد

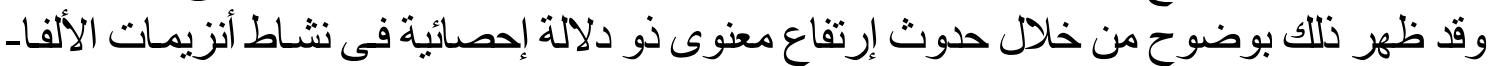

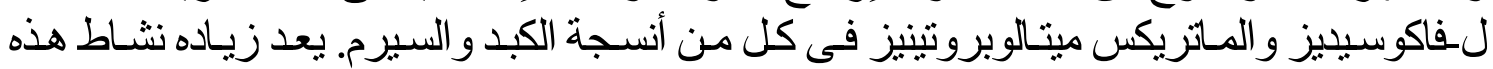

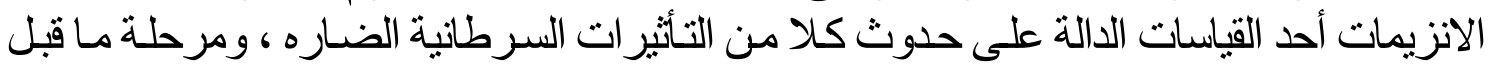

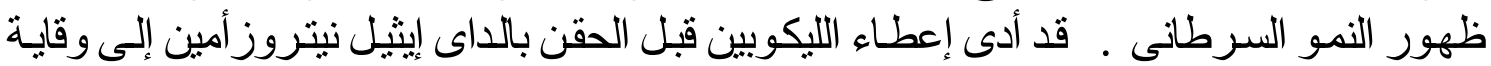

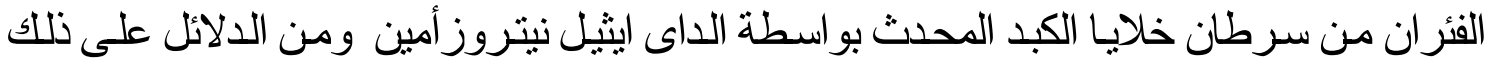

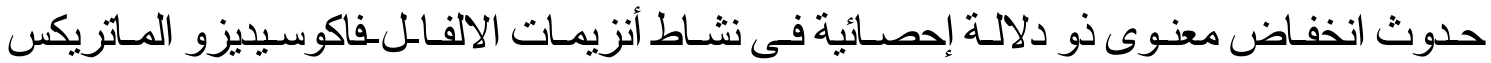

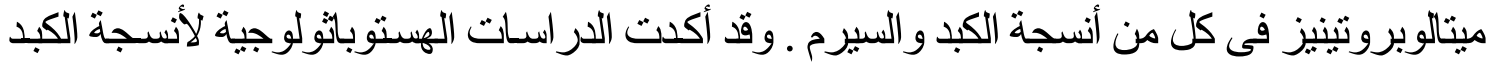

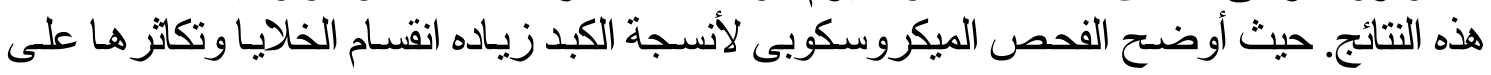

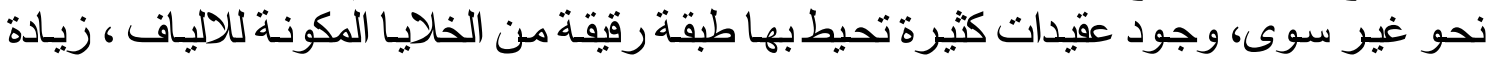

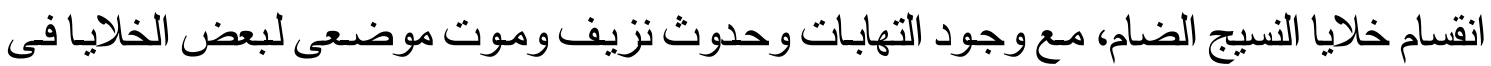

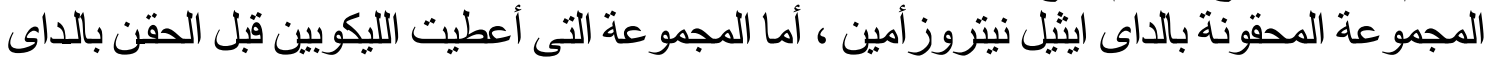

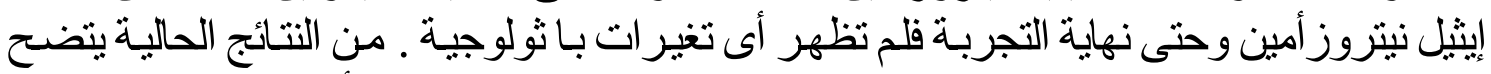
اللور الوقائى للليكو بين ضد سرطان نهانين الكبد المحدث بو اسطة الداى إيثيل نيتروز أمين. 